\title{
MENGEMBANGKAN BUDAYA DAMAI DI SEKOLAH MELALUI MANAJEMEN KELAS YANG DEMOKRATIS BERBASIS NILAI-NILAI KEISLAMAN
}

\author{
Askar \\ STAIN Datokarama Palu, Jl. Diponegoro 23 Palu \\ e-mail: askarstain67@yahoo.co.id
}

\section{Abstract}

Islam is a religion of peace. Therefore, Islam accommodates differences in religions, ethnics, languages, and cultures. Islam also recommends that peace culture be established at any time and place. One of the places where peace culture can be established is through class management at schools. Based on this, class should be managed by employing socio-emotional principles such as mutual appreciating, mutual understanding, and mutual respecting, both between students and students and students and teachers.

$$
\begin{aligned}
& \text { إن الأسلام هو دين السلام ، فإنه يتسامح فى اخلتلاف الناس فى دينهم و } \\
& \text { عرقهم ولسانهم و حضارتهم، حيث قرر الإسلام بأنحضارة التعايش السلمى } \\
& \text { بين الناس أمر لا غناء عنه فلا مفر من قيامها فى كل زمان و مكان ، و من } \\
& \text { الأماكن التى يجب أن يتقرر فيها هذا التعايش المدرسة ، و ذلك من خلال } \\
& \text { قيادة الصف فى المدرسة ، لذلك فلا بد من التراحم و التواقر و التفاهم بين } \\
& \text { التلاميذ فيما بينهم من جهة و بين التلاميذ و أساتذهم من جهة أخرى. }
\end{aligned}
$$

Kata Kunci: budaya damai, konflik, sekolah, manajeman kelas 


\section{PENDAHULUAN}

Kehidupan yang damai merupakan dambaan semua umat manusia. Kehidupan damai yang dilandasi oleh saling menghargai, saling mengohormati, dan saling menerima akan menciptakan ketenangan hidup, kesejahteraan, dan keadilan. Sebaliknya, kehidupan yang penuh konflik akan menciptkan kegalauan dan bahkan kekerasan dalam kehidupan. Kehidupan yang damai bukan hanya tuntutan sosiologis dan psikologis, tetapi juga merupakan tuntunan religius dalam semua ajaran agama. Dalam persfektif Islam, manusia dilahirkan dengan fitrah yang cenderung kepada kebenaran dan kedamaian. Dalam kondisi fitrahnya, manusia akan menyikapi kehidupan sebagai milik "bersama", di mana setiap manusia atau bangsa apa pun berhak menikmati ketenangan dan kesejahteraan hidup. Pada saat yang sama mereka memiliki kewajiban menciptakan kehidupan semacam itu dan menyebarkannya secara konkret di seluruh belahan dunia (Abd. A'la, t.th.).

Ajaran damai adalah ajaran yang bersifat universal karena terdapat dalam setiap agama dan semua peradaban. Oleh karena itu, setiap pemeluk agama dan semua manusia berkewajiban untuk selalu membangun budaya damai dalam kehidupannya. Kehidupan dan budaya damai bukan konsep semata, tetapi membutuhkan praktek secara bersama dari seluruh lapisan masyarakat. Budaya damai dapat dibangun melalui proses internalisasi budaya melalui lembaga pendidikan. Di lembaga pendidikan yang mempertemukan anak-anak bangsa dari berbagai karakter, tidak saja ditawarkan pencerahan intelektual, tetapi juga diberikan penguatan kultur kebersamaan. Lembaga pendidikan dalam semua jenjangnya adalah tempat terbaik untuk resolusi konflik yang efektif karena mereka dimungkinkan dalam jangka waktu lama mengalami, membicarakan, merefleksikan dan-dengan bimbingan guru-mengelola konflik (Tambunan, 2008).

Secara sosiologis, pendidikan bersifat fungsional dalam sistem kehidupan masyarakat. Lembaga pendidikan berperan menyiapkan generasi muda untuk hidup dalam masyarakatnya setelah dewasa tanpa kesulitan, baik secara ekonomi, politik, sosial-keagamaan, dan budaya (Sudarjito, 2003:119-120). Pendidikan menjadi salah satu faktor penentu dalam mengatasi segala masalah dan ketegangan yang dihadapi masyarakat, baik ketegangan yang bersifat individual, 
maupun ketegangan-ketegangan sosial. Lembaga pendidikan harus menjadi tempat bagi masyarakat untuk belajar menghormati hak-hak orang lain, atau kelompok lain. Menggunakan kemajuan pengetahuan untuk melestarikan perkembangan manusia daripada menciptakan perbedaan yang lebih besar antara sesama manusia, yang bermuara pada terciptanya konflik (Delors, t.th.:11).

Lembaga pendidikan memiliki peran yang sangat strategis dalam membangun budaya damai. Oleh karena itu, lembaga pendidikan perlu didesain menjadi lembaga peace building yang menyediakan berbagai program pendidikan yang menumbuhkan banyak pengalaman membangun perdamaian dan manajemen konflik (Tambunan, 2008)).

Lembaga pendidikan merupakan sarana yang sangat ideal untuk menginternaslisaikan dan membangun budaya damai, namun masalahnya adalah bagaimana menginternalisasikan dan membangun budaya damai di sekolah khususnya dalam manajemen dan pengelolaan kelas. Hal inilah yang akan dibahas dalam tulisan ini.

\section{BUDAYA DAMAI: KONSEP DAN APLIKASINYA}

Kebudayaan merupakan istilah yang memiliki beragam definisi baik dalam arti sempit maupun dalam arti yang luas. Di dalam Kamus Besar Bahasa Indonesia disebutkan bahwa "budaya" adalah pikiran, akal budi, adat istiadat. Sedangkan "kebudayaan" adalah hasil kegiatan dan penciptaan batin (akal budi) manusia, seperti kepercayaan, kesenian dan adat istiadat (Depdikbud,1996:149). Kebudayaan adalah suatu perilaku yang berpola yang ada dalam kelompok tertentu yang anggota-anggotanya memiliki makna yang sama serta simbol yang sama untuk mengkomunikasikan makna tersebut (Colleta, 1987:2). Pakar lain mengemukakan bahwa kebudayaan sebagai suatu sistem ide atau sistem gagasan milik suatu masyarakat yang dijadikan acuan bagi tingkah laku dalam kehidupan sosial dari masyarakat yang bersangkutan (Melalatoa, 1997:4).

Dari definisi di atas, dapat dipahami bahwa budaya adalah suatu sistem dan pola tingkah laku dalam suatu masyarakat tertentu, yang diperoleh melalui proses belajar, yaitu hasil pemikiran dan refleksi individu terhadap sistem budaya yang ada, dan cermin interaksi praksis individu dengan masyarakat di mana dia hidup. Hasil belajar individu memungkinkan lahirnya budaya baru. 
Kehidupan damai sesungguhnya dapat dikembangkan sehingga menjadi suatu sistem budaya dalam masyarakat. Budaya damai adalah sistem budaya yang mencerminkan pemikiran, sikap dan perilaku sehingga menciptakan suasana kehidupan yang menghargai kesejahteraan, kebebasan, dan keadilan (Lattu, 2008)). Persamaan hak atau kesetaraan memungkinkan terjadinya harmoni kehidupan dalam masyarakat yang tidak membedakan antara satu individu dengan individu lainnya atas dasar agama, etnis dan latar belakang budaya lainnya.

Perbedaan kelompok, etnis, dan suku akan melahirkan berbagai sifat, watak, perilaku, dan keragaman budaya, sehinga memunculkan suasana saling mengenal dan saling memahami budaya masingmasing. Perbedaan-perbedaan merupakan potensi untuk membangun komunikasi dan merekatkan perdamaian, namun dapat pula menjadi akar pemicu dan pemacu konflik. Ajaran Islam menekankan bahwa perbedaan laki-laki dan perempuan serta perbedaan suku dan bangsa dimaksudkan agar masing-masing saling mengenal. Allah berfirman dalam Q.S Al-Khujurât (49):13 sebagai berikut:

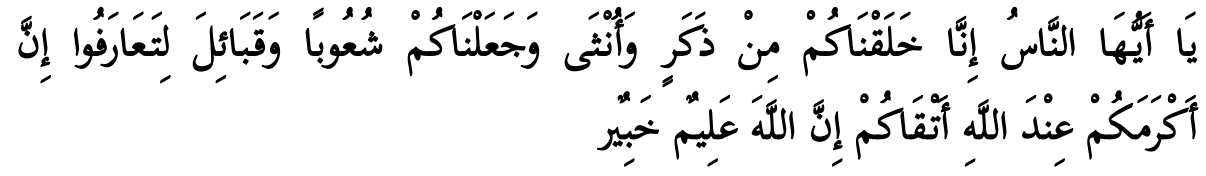

Terjemahnya:

Hai manusia, sesungguhnya Kami menciptakan kamu dari seorang laki-laki dan seorang perempuan dan menjadikan kamu berbangsa-bangsa dan bersuku-suku supaya kamu saling kenalmengenal. Sesungguhnya orang yang paling mulia diantara kamu disisi Allah ialah orang yang paling taqwa diantara kamu. Sesungguhnya Allah Maha Mengetahui lagi Maha Mengenal.

Shihab (2002:262) menjelaskan bahwa:

Kata (تعارفوا ) ta'ârafû terambil dari kata (عرف) 'arafa yang berarti mngenal. Patron kata yang digunakan ayat ini mengandung makna timbal balik, dengan demikian ia berarti saling mengenal. Semakin kuat pengenalan satu pihak kepada selainnya, semakin terbuka untuk saling memberi manfaat. Karena itu ayat di atas menekankan perlunya saling mengenal. Perkenalan itu dibutuhkan untuk saling menarik pelajaran dan pengalaman pihak lain, guna meningkatkan ketaqwaan kepada Allah swt., yang dampaknya tercermin pada kedamaian dan 
kesejahteraan hidup duniawi dan kebahagiaan ukhrawi. Anda tidak dapat menarik pelajaran, tidak dapat saling melengkapi dan menarik manfaat, bahkan tidak dapat bekerja sama tanpa saling kenal mengenal.

Penekanan Alquran dan penafsiran sebagaimana dikemukakan di atas menunjukkan bahwa budaya damai hanya dapat dibangun jika semua individu yang ada di dalam masyarakat itu saling mengenal dalam arti yang luas. Saling mengenal hanya dapat dibangun jika semua individu membangun sikap dan perilaku saling menghargai, saling mengerti, saling memahami, dan menghilangkan prasangka negatif terhadap orang lain atau kelompok lain.

Islam adalah agama perdamaian. Itulah sebabnya Allah meniscayakan kepada hamba-Nya untuk masuk ke dalam Islam (kedamaian) secara kâffah. Allah berfirman dalam Q.S Al-Baqarah (2):208 sebagai berikut:

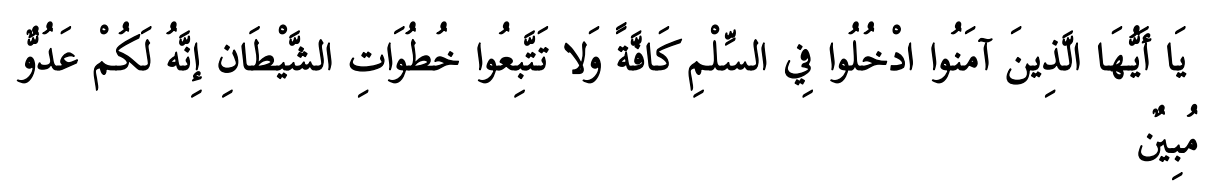

Terjemahnya:

Hai orang-orang yang beriman, masuklah kamu ke dalam Islam keseluruhan, dan janganlah kamu turut langkah-langkah syaitan. Sesungguhnya syaitan itu musuh yang nyata bagimu. berikut:

Shihab (2002:262) menguraikan penafsiran ayat ini sebagai

Kata ( السلم as-Silm yang dalam ayat di atas diterjemahkan dengan kedamaian atau Islam, makna dasarnya adalah damai atau tidak mengganggu. Kedamaian oleh ayat ini diibaratkan berada disuatu wadah yang dipahami dari kata (في ) fi, yakni dalam. Yang beriman diminta untuk memasukkan totalitas dirinya ke dalam wadah itu secara menyeluruh, sehingga semua kegiatannya berada dalam wadah atau koridor kedamaian. Ia damai dengan dirinya, keluarganya, dengan seluruh manusia, binatan dan tumbuh-tumbuhan serta alam raya. Walhasil (كافة ) kâffah, yakni secara menyeluruh tanpa kecuali. Ayat ini menuntut setiap yang beriman agar melaksanakan seluruh ajaran Islam. Jangan hanya percaya dan mengamalkan sebagian ajarannya dan menolak atau mengabaikan sebagian yang lain. Ia dapat juga bermakna masuklah kamu semua kâffah tanpa kecuali, jangan seorangpun di antara kamu yang tidak masuk ke dalam ke damaian/Islam. 
Manusia muslim yang mengaplikasikan imannya secara total dapat dipastikan akan selalu menebar rasa aman, karena kata-kata "iman" dan kata "aman" berasal dari akar kata yang sama. Orang yang beriman akan selalu diliputi rasa aman sehingga menjadi manusia yang penuh rasa percaya diri, memiliki penampilan yang simpati dan empati terhadap orang lain, toleran bersahabat, dan damai, tidak mudah tersinggung dan berprasangka buruk terhadap orang lain (Madjid, 1995:16-17). Sifat mudah tersinggung dan berprasangka buruk terhadap orang lain adalah sikap yang selalu mengundang konflik dan bahkan kekerasan dan menjauhkan perdamaian. Oleh karena itu, dalam pandangan Islam, sikap ini hanya dapat dihilangkan dengan memasukkan diri ke dalam Islam dan beriman secara total.

Upaya untak menciptakan perdamaian adalah tugas kemanusiaan sepanjang sejarah yang turut mewarnai peradaban. Menciptakan perdamaian merupakan langkah kongkret untuk menghilangkan konflik dan kekerasan. Namun demikian, perlu dikemukakan bahwa konflik dan kekerasan telah ada sejak manusia ada, dan akan terus mewarnai kehidupan manusia jika tidak ada upaya untuk menegakkan perdamaian.

Dengan demikian, komitmen terhadap perdamaian harus lebih penting dari negara, agama, ras, dan ikatan-ikatan etnik. Dalam kehidupan negara yang pluralistik seperti Indonesia, dialog antar kebudayaan dan antar agama menjadi aktivitas sentral yang dapat memelihara budaya perdamaian dan memelihara agar agama tidak digunakan untuk melegalkan kekerasan, termasuk dalam bentuk konflik atau perang antar negara, pembunuhan massal, menginjakinjak hak asasi orang lain, terorisme, dan kekerasan yang terorganisasi (Muzadi, 2006).

Komitmen untuk membudayakan perdamaian dan mengurangi budaya kekerasan merupakan inti ajaran semua agama. Dalam pandangan agama Islam, budaya perdamaian harus diciptakan di atas norma-norma dan prinsip-prinsip non-kekerasan (salâm), keadilan ('adâlah), kebebasan (hurriyah), moderatisasi (tawassut $\square$ ), toleransi (tasâmuh), keseimbangan (tawâzun), musyawarah (syûrâ), dan persamaan (musâwah). Budaya perdamaian hanya bisa diwujudkan jika seluruh norma dan prinsip ini terjelma dalam diri sendiri, keluarga, masyarakat, negara dan dunia. Sebagaimana yang dicontohkan Rasulullah saw., Nabi Isa as., Sidharta Gautama, Guru 
Nanak, dan tokoh-tokoh filosof lainnya. Hal ini jualah yang dilakukan oleh Mennonites dan Quakers di eranya (Muzadi, 2006).

\section{MANAJEMEN KELAS YANG DEMOKRATIS UNTUK MENUMBUHKEMBANGKAN BUDAYA DAMAI DALAM DIRI SISWA}

Pengelolaan atau manajemen kelas (classroom management) adalah serangkaian tindakan guru yang ditujukan untuk mendorong munculnya tingkah laku yang diharapkan dan menghilangkan tingkah laku yang tidak diharapkan, menciptakan hubungan interpersonal yang baik dan iklim sosio-emosional yang positif, serta menciptakan dan memelihara organisasi kelas yang produktif dan efektif (Julaeha, dalam Anita (2007:106). Pengertian lain dari manajemen atau pengelolaan kelas adalah teknik atau metode yang dilakukan oleh guru untuk menciptakan lingkungan kelas agar tidak terjadi kekacauan dan memberikan kesempatan kepada siswa untuk mencapai tujuan akademis dan sosial (Winzer, 1995). Peran guru dalam manajemen kelas seperti ini adalah menciptakan suatu iklim kelas yang sehat yang dapat mengembangkan sosio-emosional kelas yang positif melalui hubungan interpersonal yang sehat, baik antara guru dengan siswa maupun antara siswa dengan siswa lainnya (Julaeha, 2007:106), sehingga tujuan pembelajaran, baik secara akademis maupun sosial dapat tercapai.

Ada beberapa pendekatan dalam pengelolaan kelas, dua di antaranya yang saling bertolak belakang adalah pendekatan otoriter dan pendekatan iklim sosio-emosional. Pendekatan yang otoriter dalam pengelolaan kelas merupakan seperangkat kegiatan guru untuk menciptakan dan mempertahankan ketertiban suasana kelas. Pengelolaan kelas sebagai proses untuk mengontrol tingkah laku siswa ke arah disiplin. Bila timbul masalah-masalah yang merusak ketertiban atau kedisplinan kelas, perlu dilakukan pendekatan perintah dan larangan, penekanan dan penguasan, penghukuman dan pengancaman. Pendekatan iklim sosio-emosional adalah pendekatan yang memandang bahwa pengelolaan kelas yang efektif merupakan fungsi dari hubungan yang baik antara pengajar dan pembelajar, antara pembelajar dan pembelajar; menumbuhkan sikap kesadaran diri sendiri, keterbukaan, sikap menerima, menghargai mau mengerti dan menaruh rasa empati, penerimaan diri, dan rasa empati. Dengan kata 
lain pendekatan iklim sosio-emosional merupakan suatu manajemen kelas yang demokratis yang menekankan pada sikap saling menerima dan saling menghargai, serta menyelesaikan masalah di kelas melaluii dialog dalam bentuk pertemuan kelas.

Dari hasil pengamatan secara sepintas masih ditemukan banyak guru yang menggunakan pendekatan otoriter dalam manajemen kelas. Hal ini tampak jelas dalam sistem penempatan siswa di tiap kelas dan pengaturan siswa di dalam kelas. Penempatan siswa di tiap kelas dilakukan berdasarkan tingkat kognitifnya atau berdasarkan kencerdasan intelektualnya, yang pintar ditempatkan dalam satu kelas tertentu dan siswa yang bodoh dan berperilaku nakal ditempatkan dalam satu kelas di kelas lain. Urutan kelasnya biasanya diurut berdasarkan abjad. Misalnya, di kelas 1A untuk siswa yang paling pintar, dan di kelas $1 \mathrm{~F}$ untuk anak yang bodoh dan berperilaku nakal. Alasan yang dikemukakan oleh guru adalah agar siswa yang nakal tidak mempengaruhi siswa yang lain untuk meniru perilakunya, tidak saling mengganggu dan mudah diawasi, serta diberi pembinaan yang lebih terarah.

Begitu pula dalam hal pengaturan siswa di dalam kelas. Realitas menunjukkan bahwa penempatan siswa di dalam kelas juga masih sangat otoriter. Sebagai contoh apabila siswa sejak awal masuk di kelas sudah duduk dibangkunya dan duduk dengan teman sebangkunya yang lain, maka siswa bersangkutan tidak boleh lagi pindah ke meja lain untuk belajar, begitu pula dengan teman sebangkunya. Alasan yang dikemukakan hampir sama, yaitu agar mudah diawasi, dan agar siswa bertanggunng jawab terhadap meja dan kursi yang ia tempati, baik dari segi keamanan maupun kebersihannya.

Siswa ditempatkan pada suatu kelas tertentu berdasarkan tingkat kognitifnya dan siswa yang nakal ditempatkan pada kelas tertentu pula dengan alasan agar mudah diawasi. Di satu sisi, tampaknya sangat rasional, namun di sisi lain secara psikologis hal ini dapat merusak mental anak, baik bagi siswa yang tingkat kognitifnya baik dan tidak berperilaku nakal, maupun bagi siswa yang berperilaku nakal. Bagi anak yang tingkat intelektualnya baik dan ditempatkan dalam satu kelas dengan apa pun nama kelas itu, seperti kelas unggulan atau kelas kompetitif, dapat menimbulkan sikap eksklusif kelas, dan memandang kelasnya dan dirinya jauh lebih baik, lebih pintar, lebih unggul 
daripada temannya yang lain. Sebaliknya, di kelas yang semua siswanya dianggap nakal, juga akan memungkinkan munculnya sikap eksklusif kelas dalam bentuk yang lain, dengan memunculkan perilaku-perilaku negatif. Hal ini dilakukan untuk menutupi perasaan inferior mereka terhadap kelas unggulan, serta menunjukkan identitas mereka. Sikap eksklusif kelas ini pula yang kemudian mempengaruhi mahasiswa sehingga biasa terjadi tawuran antar mahasiswa berdasarkan fakultasnya. Mereka menganggap fakultasnya yang paling favorit, sedamgkan fakultas lain adalah fakultas nomor dua dan sebagainya.

Begitu pula dalam hal penempatan siswa di dalam kelas berdasarkan tempat duduk dan teman sebangkunya. Karena mereka sejak masuk sudah duduk di bangku paling depan dan dengan teman sebangkunya, mereka tidak pindah lagi ke bangku lain, begitu pula temannya. Akibatnya, muncul anggapan dalam diri siswa bahwa bangku yang ditempatinya adalah miliknya dan orang lain tidak boleh menggunakannya. Di sisi lain juga dapat memunculkan sikap pertemanan yang eksklusif, mereka mengganggap bahwa teman sebangukunyalah yang paling baik.

Manajemen kelas yang otoriter dan menempatkan siswa berdasarkan tingkat kognitifnya tanpa disadari telah melakukan kekerasan psikologis kepada siswa. Karena pembagian kelas seperti itu justru memberikan beban mental yang berat kepada siswa, sekaligus membatasi interaksi mereka. Padahal melakukan kekerasan psikologis justru akan membuat siswa semakin menjauh dan akan menumbuhkan sikap eksklusifisme. Allah juga memperingatkan hal ini dalam Q.S Ali Imrân (3):159:

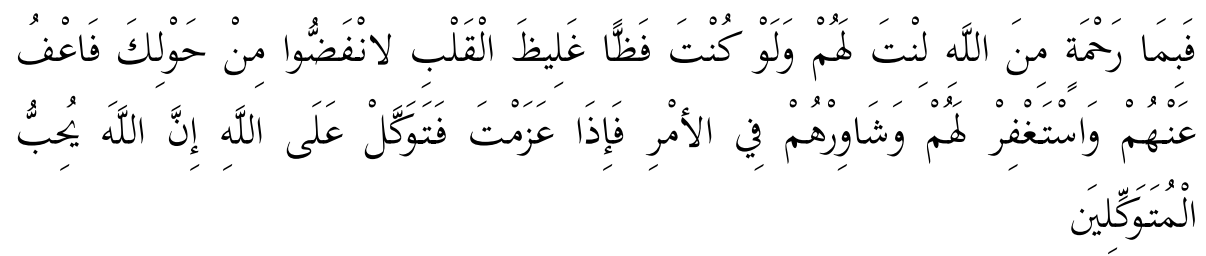

Terjemahnya:

Maka disebabkan rahmat dari Allah-lah kamu Berlaku lemah lembut terhadap mereka. Sekiranya kamu bersikap keras lagi berhati kasar, tentulah mereka menjauhkan diri dari sekelilingmu. karena itu ma'afkanlah mereka, mohonkanlah 
ampun bagi mereka, dan bermusyawaratlah dengan mereka dalam urusan itu. kemudian apabila kamu telah membulatkan tekad, Maka bertawakkallah kepada Allah. Sesungguhnya Allah menyukai orang-orang yang bertawakkal kepada-Nya.

Ayat di atas memberikan petunjuk yang jelas bahwa melakukan kekerasan baik kekerasan fisik maupun kekerasan psikologis hanya akan menyebabkan seseorang semakin menjauh. Ayat ini mengisyaratkan bahwa jika guru melakukan kekerasan fisik dan kekerasan psikologis hanya akan menyebabkan siswa itu semakin manjauhi gurunya. Kekerasan psikologis yang dimaksud bukan sekedar memberikan kata-kata kasar, tetapi memberi perlakuan yang tidak adil, membeda-bedakan antara satu siswa dengan siswa yang lainnya, seperti membedakan kelas berdasarkan faktor kognitif, dan kenakalannya justru akan membuat menjauh. Sebaliknya, jika semua siswa diperlakukan dengan penuh kelembutan dengan membangun iklim sosio-emosional yang baik justru akan menumbuhkan sikap dan perilaku siswa yang saling menghargai dan saling menerima.

Perlakuan membeda-bedakan siswa berdasarkan tingkat kecerdasan intelektualnya samata atau mengisolir mereka yang berperilaku nakal dalam kelas tertentu justru hanya akan membentuk sikap yang eksklusif. Sikap eksklusif kelas akan mendorong siswa untuk memandang bahwa kelasnya yang paling baik, dan akan menunjukkan sikap-sikap eksklusif sebagai identitas kelasnya, kelas yang pintar akan memperlihatkan kesombongan, dan kelas yang dianggap nakal akan memperlihatkan kenakalan-kenakalannya.

Sikap memandang kelompok sebagai kelompok yang paling baik dan bersikap eksklusif termasuk perbuatan yang zalim. Allah berfirman dalam Q.S Al-Hujurât (49):11 sebagai berikut:

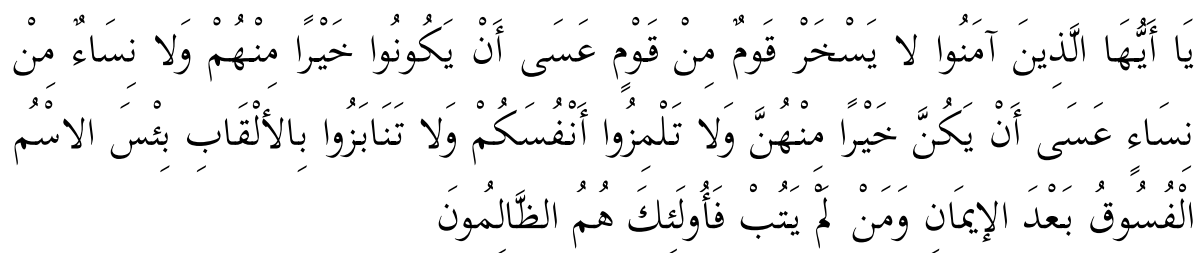

Terjemahnya:

Hai orang-orang yang beriman, janganlah sekumpulan orang laki-laki merendahkan kumpulan yang lain, boleh jadi yang ditertawakan itu lebih baik dari mereka. Dan jangan pula 
sekumpulan perempuan merendahkan kumpulan lainnya, boleh jadi yang direndahkan itu lebih baik. Dan janganlah suka mencela dirimu sendiri dan jangan memanggil dengan gelaran yang mengandung ejekan. Seburuk-buruk panggilan adalah (panggilan) yang buruk sesudah iman dan barangsiapa yang tidak bertobat, maka mereka itulah orang-orang yang zalim.

Memberikan perlakuan yang berbeda kepada seseorang akan dapat membentuk sikap curiga dan prasangka di dalam diri orang itu. Hal ini akan sangat berpengaruh buruk pada perilakunya. Orang atau guru melakukan diskriminasi dan tidak adil kepada anak atau siswanya akan berpotensi untuk membentuk pola pikir dan sikap anak atau siswa yang selalu berperasangka buruk dan hal ini akan mempengaruhi perilakunya. Hal ini sebagaimana dikisahkan oleh Allah dalam Q.S Yûsuf (12):8-9.

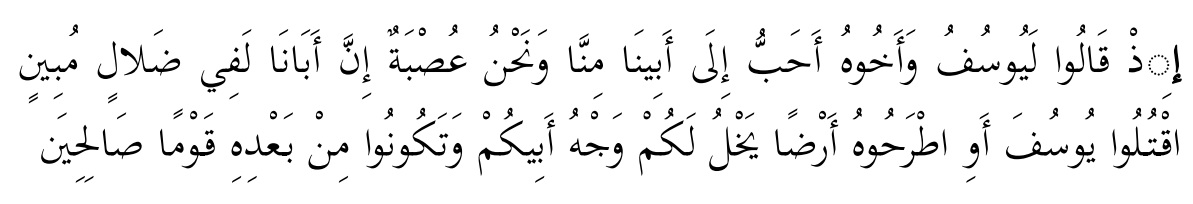

Terjemahnya:

(Yaitu) ketika mereka berkata: "Sesungguhnya Yusuf dan saudara kandungnya (Bunyamin) lebih dicintai oleh ayah kita dari pada kita sendiri, padahal kita (ini) adalah satu golongan (yang kuat). Sesungguhnya ayah kita adalah dalam kekeliruan yang nyata. Bunuhlah Yusuf atau buanglah dia kesuatu daerah (yang tak dikenal) supaya perhatian ayahmu tertumpah kepadamu saja, dan sesudah itu hendaklah kamu menjadi orang-orang yang baik.

Ayat di atas memberikan petunjuk yang jelas bahwa perlakuan yang tidak adil akan melahirkan prasangka yang buruk dan membentuk perilaku negatif dalam diri seseorang. Prasangka buruk akan mendorong seseorang untuk menjauhi orang yang diprasangkainya. Sikap ini kemudian akan menyebabkan terputusnya komunikasi dan interaksi. Akibat yang lebih parah dari kondisi ini adalah lahirnya pertentangan, perselisihan, dan bahkan konflik. 
Membangun suasana kelas yang demokratis, diperlukan komunikasi yang intens dan selalu duduk bersama menatap setiap masalah yang timbul dan memecahkannya secara bersama melalui musyawarah. Membiasakan siswa terlibat dalam suasana komunikasi yang intens dan harmonis akan mendidik mereka untuk selalu berkomunikasi dan berdialog dalam memecahkan masalah sekaligus menghindarkan mereka dari sikap memaksakan kehendak.

Komunikasi interaktif perlu dilakukan oleh pengajar yang berorientasi pada pembelajar. Komunikasi interaktif yang berumber dari iklim sosiologis dan psikologis yang menyenangkan memungkinkan siswa berkumpul dan bergaul dalam suasana yang tentram dan saling melindungi. Penciptaan iklim sosio-emosional terjadi bila terdapat keterlibatan pengajar dalam suasana belajar yang demokratis. Iklim ini mendidik siswa untuk mengembangkan tanggung jawab sosial dan merasa dirinya "berarti" bagi orang lain. Bagi mereka yang melakukan perilaku menyimpang hendaknya dibantu untuk memperbaiki diri. Salah satu cara yang dapat dilakukan untuk mengatasi masalah kelas/kelompok hendaknya melalui pertemuan kelas untuk memecahkan masalah sosial (http:// pakdesofa.blog2.plasa.com/ archives/22).

Di sekolah sejak dini harus dibiasakan siswa untuk berperilaku secara luwes melalui suasana kelas yang dinamis. Hal ini dapat dibangun dengan membiasakan siswa bertanggung jawab secara bersama terhadap semua fasilitas sekolah. Semua siswa berhak atas seluruh fasilitas sekolah dan fasilitas kelas sehingga semua siswa di dalam kelas berhak menikmati fasilitas yang ada di kelas itu. Padai saat yang sama semua siswa diberi tanggung jawab yang sama untuk menjaga semua fasilitas yang ada di kelas itu. Semua siswa berhak untuk duduk di bangku dan duduk dengan teman yang ia senangi. Iklim seperti ini harus dibiasakan kepada siswa sehingga sejak dini mereka dilatih untuk luwes dalam bergaul dan berkomunikasi.

Perlakuan guru yang adil dan tidak membeda-bedakan antara satu siswa dengan yang lainnya, suasana kelas yang harmonis saling menghargai dan menghormati, siswa merasa aman dan sejahtera adalah pilar-pilar utama untuk membangun kelas yang demokratis. Iklim kelas yang demokratis yang dibangun sejak dini akan mendidik dan dapat membentuk sikap untuk selalu berdamai dengan sesamanya. Kondisi ini memberi bekal kepada siswa kelak ketika terjun ke 
masyarakat untuk menampilkan perilaku-perilaku yang telah tumbuh dan dibiasakan dalam diri mereka sejak dini.

\section{PENUTUP}

Sebagai bangsa yang memiliki keragaman suku, etnis, bahasa, budaya, dan agama, diperlukan kearifan-kearifan sosial sehingga perbedaan-perbedaan yang ada tidak menjadi sumber pertentangan dan konflik tetapi justru menjadi sumber untuk membangun kedamaian dan kebersamaan di atas keragaman. Membangun budaya damai harus dimulai sejak dini di sekolah dengan membiasakan para siswa dan siswi untuk saling berinteraksi dan berkomunikasi dengan sesamanya tanpa sekat-sekat agama. Untuk itu, diperlukan iklim dan pengelolaan kelas yang demokratis dengan memperlakukan siswa dan siwi secara adil, memberi kesempatan kepada mereka untuk mengemukakan pendapat dan keinginan-keinginannya, dan membiasakan mereka untuk selalu duduk bersama dan berdialog dalam menatap dan menyelesaikan masalahnya.

\section{DAFTAR PUSTAKA}

Abd. A’la, Kekuatan Melawan Kekerasan yang Dehumanistik Moralitas Demokrasi-Teologis, http://www.unisosdem.org/ article detail.php? aid $=1907 \&$ coid $=3 \&$ caid $=22 \&$ gid $=3$, diakses 2 september 2008 .

Anonim. Pendekatan dalam Pengelolaan Kelas. http://pakdesofa.blog2 .plasa.com/archives/22, diakses 1 September 2008.

Arsyad, Azhar. 2003. Pokok-Pokok Manajemen; Pengetahuan Praktis bagi Pimpinan dan Eksekutif. Cet. ke-2. Yogyakarta: Pustaka Pelajar.

Colletta, Nat. J. 1987. dalam Kebudayaan dan Pembangunan; Sebuah Pendekatan terhadap Antropologi Terapan di Indonesia. Jakarta: Yayasan Obor Indonesia.

Delors, Jacques. t.th. Education the Necessary Utopia, in Learning the Treasure Within. New York: UNESCO Publishing.

Departemen Agama RI., 1992. Al-Qur'an dan Terjemahnya. Jakarta: PT. Intermasa.

Departemen Pendidikan dan Kebudayaan RI., 1996. Kamus Besar Bahasa Indonesia. Edisi. ke-2. Cet. ke-7. Jakarta: Balai Pustaka.

Julaeha, Siti 2007. Pengelolaan Kelas. Dalam Anita, Sri W, dkk. Strategi Pembelajaran di SD. Modul. Jakarta: Universitas Terbuka.

Lattu, Izak Y. M. Budaya Damai dalam Masyarakat Multikultural, http://izaklattu.edublogs.org/2008/01/31/budaya-damai-dalammasyarakat-multikultural/,diakses 3 September 2008.

Madjid, Nurcholish. 1995. Pintui-Pintu Menuju Tuhan. Jakarta: Paramadina. 
Melalatoa, M. Junus. 1997. Rujukan Studi Indonesia. Dalam M. Junus Melalatoa (Ed.) Sistem Budaya Indonesia. Jakarta: Pamator.

Muzadi, Hasyim. Mengembangkan Budaya Damai. 03 November 2006,http://www.cmm.or.id/cmm-ind_more.php?id=A3030 0_3_0 M.

Tambunan, Frietz T., "Peacebuilding", Kurikulum Bangsa. http://www.kompas.com, diakses 5 September 2008.

Shihab, M. Quraish. 2002. Tafsir Al-Misbah, Pesan, Kesan dan Keserasian Al-Qur'an.Vol. 13. Jakarta: Lentera Hati.

Sudarjito. 2003. Rekonstruksi Kurikulum untuk Menunjang Berfungsinya Lembaga Pendidikan sebagai Pusat Pembudayaan Kemampuan, Nilai dan Sikap. Dalam Syafnir Ronisef, dkk. (Eds), Mengurai Benang Kusut Pendidikan; Gagasan Para Pakar Pendidikan. Jakarta: Tranformasi UNJ.

Winzer, M. 1995. Educational Psychology in the Canadian Classroom. Edisi ke-2. Ontario: Allyn and Bacon. 